Bond University

Research Repository

\title{
5-HT2A receptor enhancement of contractile activity of the porcine urothelium and lamina propria
}

Moro, Christian; Edwards, Lily; Chess-Williams, Russ

Published in:

International Journal of Urology

DOI:

10.1111/iju. 13172

Licence:

Other

Link to output in Bond University research repository.

Recommended citation(APA):

Moro, C., Edwards, L., \& Chess-Williams, R. (2016). 5-HT2A receptor enhancement of contractile activity of the porcine urothelium and lamina propria. International Journal of Urology, 23(11), 946-951.

https://doi.org/10.1111/iju.13172

\section{General rights}

Copyright and moral rights for the publications made accessible in the public portal are retained by the authors and/or other copyright owners and it is a condition of accessing publications that users recognise and abide by the legal requirements associated with these rights.

For more information, or if you believe that this document breaches copyright, please contact the Bond University research repository coordinator 
$5-\mathrm{HT}_{2 \mathrm{~A}}$ receptor enhancement of contractile activity of the porcine urothelium and lamina propria

\section{Christian Moro, Lily Edwards and Russ Chess-Williams}

Centre for Urology Research, Faculty of Health Sciences and Medicine, Bond University, University Drive, Gold Coast, Australia. 4229.

Running title: 5-HT and the urothelium/lamina propria

Note: this is a pre-proof version of this manuscript. The final version can be found at:

Wiley Online Library: http://onlinelibrary.wiley.com/doi/10.1111/iju.13172/full

To reference this article:

Moro, C., Edwards, L., \& Chess-Williams, R. (2016). 5-HT2A receptor enhancement of contractile activity of the porcine urothelium and lamina propria. Int $J$ Urol. [ePub ahead of print]. doi:

10.1111/iju.13172 


\begin{abstract}
Objectives:

The urothelium and lamina propria play important roles in the maintenance of normal bladder function. Recently, contraction has been added to the properties the tissue possesses, but little is known about the mechanisms regulating this activity. This study examines the actions of 5-HT (serotonin) on the contractile properties of the urothelium and lamina propria, since a better understanding of bladder physiology may aid the development of new treatments.

Methods:

Strips of porcine urothelium and lamina propria were suspended in gassed Krebs-bicarbonate solution and cumulative concentration-response curves to 5-HT were generated in the absence and presence of 5-HT antagonists, L-NNA and indomethacin. Responses to $\alpha$-methyl-5-hydroxytryptamine were also examined.

Results:

Strips of urothelium/lamina propria developed spontaneous contractions, while the addition of 5-HT induced concentration-dependent increases in contractile tone with maximal contractions of $50.43 \pm$ $2.78 \mathrm{mN}$ per gram tissue weight $(\mathrm{n}=100)$. Tonic contractions to 5 -HT were unchanged in the presence of L-NNA $(100 \mu \mathrm{M})$ or indomethacin $(5 \mu \mathrm{M})$. Selective concentrations of the antagonists methiothepin (5-HT $1 \& 2,100 \mathrm{nM}), \mathrm{RS} 102221\left(5-\mathrm{HT}_{2 \mathrm{C}}, 30 \mathrm{nM}\right)$, ondansetron $\left(5-\mathrm{HT}_{3}, 30 \mathrm{nM}\right), \mathrm{GR} 113808,\left(5-\mathrm{HT}_{4}\right.$,

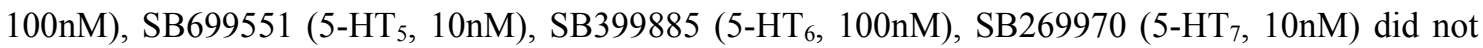
influence responses to 5-HT. However, the 5- $\mathrm{HT}_{2 \mathrm{~A}}$ antagonist ketanserin $(30-300 \mu \mathrm{M})$ caused a shift of the 5-HT curve yielding an affinity estimate of 7.9.

Conclusions:

The results indicate that contractile responses of the urothelium/lamina propria to 5-HT are predominantly mediated via the $5-\mathrm{HT}_{2 \mathrm{~A}}$ receptor.
\end{abstract}

Keywords: 5-HT, bladder, Serotonin, lamina propria, urothelium. 


\section{Introduction:}

Bladder dysfunction is a common urological condition, yet the underlying mechanisms involved in maintaining normal continence are still not fully understood. Whilst the detrusor is the main muscle responsible for bladder contraction and micturition, the urothelium and lamina propria (urothelium/LP) is now recognised as a responsive tissue that performs important functions detecting a range of mechanical and chemical stimuli and transducing these signals to closely located afferent nerves, myofibroblasts and smooth muscle. ${ }^{1}$ A range of receptors are located on the urothelium, including P2X and $\mathrm{P} 2 \mathrm{Y}$ receptors ${ }^{2}$, muscarinic, nicotinic ${ }^{3}, \alpha$ and $\beta$ adrenergic receptors ${ }^{4}$ and oestrogen receptors ${ }^{5}$. In recent years another property of the urothelium/LP has been recognised, where the urothelium/LP develops both phasic and tonic contractile activity, with spontaneous contractions developing in isolated strips of urothelium/LP in the absence of any external stimulation. ${ }^{6}$ Tonic contractions can be stimulated in isolated tissues through a range of receptors including muscarinic M3, ${ }^{6}$ tachykinin NK2, ${ }^{7}$ and adrenergic alpha1-adrenoceptors, ${ }^{4}$ whilst nitric oxide ${ }^{8}$ and beta-adrenoceptor ${ }^{4}$ stimulation inhibit contractile activity. Physiologically, this activity could serve several purposes, including a role in folding of the urothelium when the bladder is empty, maintaining neuronal afferent sensitivity, or mediating the spontaneous contractile activity of the detrusor in disease. ${ }^{9,10}$

5-Hydroxytryptamine (5-HT) is a monoamine neurotransmitter that has a range of roles throughout the body, including regulation of bowel motility, neurological processes and cardiovascular function. ${ }^{11}$ In the lower urinary tract 5-HT exerts a number of effects. These include enhancement of acetylcholine release from parasympathetic nerves via pre-junctional $5-\mathrm{HT}_{4}$ receptors in the pig ${ }^{12}$ and human bladder, ${ }^{13}$ and relaxation of the urethra of the pig via $5-\mathrm{HT}_{7}$ receptors. ${ }^{14}$ There is indirect evidence suggesting 5-HT endogenous synthesis and release in the rat urinary bladder ${ }^{15}$, and it has been suggested that $5-\mathrm{HT}$ is also released from mast cells infiltrating the lamina propria. ${ }^{16}$ The expression of $5-\mathrm{HT}_{2 \mathrm{~A}}$, $5-\mathrm{HT}_{2 \mathrm{~B}}, 5-\mathrm{HT}_{3 \mathrm{~A}}, 5-\mathrm{HT}_{4}$ and $5-\mathrm{HT}_{7}$ have been identified in both the urothelium and detrusor of patients with normal functioning bladders, and also patients with benign prostatic hyperplasia using Real-Time

Reverse Transcription Polymerase Chain Reaction. ${ }^{17}$ This study also identified the presence of 5- $\mathrm{HT}_{2 \mathrm{~B}}$ and $5-\mathrm{HT}_{7}$ receptors in these patients using Immunohistochemistry. ${ }^{17}$ However, no studies have ever examined the influence of 5-HT on urothelial contractile activity. The aim of the present study was to examine the effects of 5-HT on the contractile properties of the porcine urothelium/LP and identify the predominant receptor subtype responsible for mediating these responses.

\section{Methods}

\section{Functional Organ Bath Studies}

Fresh bladders from large White-Landrace pigs (aged 6 months, weight $\sim 80 \mathrm{~kg}$ ) were obtained from a local abattoir and immediately immersed in cold Krebs-bicarbonate solution $\left(\mathrm{NaCl} 118.4 \mathrm{mM}, \mathrm{NaHCO}_{3}\right.$ $24.9 \mathrm{mM}, \mathrm{CaCl}_{2} 1.9 \mathrm{mM}, \mathrm{MgSO}_{4} 2.41 \mathrm{mM}, \mathrm{KCl} 4.6 \mathrm{mM}, \mathrm{KH}_{2} \mathrm{PO}_{4} 1.18 \mathrm{mM}$ and D-glucose $11.7 \mathrm{mM}$ ). The bladders were opened longitudinally, and full-thickness strips of the anterior wall from the dome region were removed. From these tissues, strips of urothelium with lamina propria were prepared $(20 \times$ $5 \mathrm{~mm}$ ) and immersed in Krebs-bicarbonate solution in $10 \mathrm{~mL}$ organs baths (Labglass, Brisbane, Australia) maintained at $37^{\circ} \mathrm{C}$ and gassed with $5 \%$ carbon dioxide in oxygen. The tissues were attached to isometric force transducers (MCT050/D, ADInstruments, Castle Hill, Australia), and tensions recorded with a Powerlab system using Labchart, version 7, software (ADInstruments). After washing with fresh Krebs solution, the tissues were allowed to equilibrate for 45 minutes before starting the addition of drugs. For studies with the antagonists, adjacent pieces of tissue were dissected, set up in pairs under identical conditions, and allowed to equilibrate. One tissue was incubated with the antagonist for 20 minutes, and the other was used as a control in the absence of any antagonist. 
Concentrations of antagonist that would be selective for particular receptor subtypes were carefully determined using affinity values appearing in the literature.

Measurements of the frequency and baseline tension were taken at the peak response after the addition of each agonist. The frequency of contractions was expressed as the number of phasic waves per minute (cycles/min) and the baseline tension as Newton force per gram tissue weight (average tissue weight: $0.25 \pm 0.004 \mathrm{~g}$ ). The baseline tension was taken as the lowest point of the spontaneous phasic contractions. Concentration-response curves were analysed using Graphpad Prism (v6) software (GraphPad, San Diego, CA). Mean ( \pm sem) pEC50 values obtained in the absence and presence of antagonists were compared using a Student's 2 -tailed paired $t$-test, with $\mathrm{P}<.05$ considered statistically significant. For ketanserin, where a range of concentrations were examined, a one-way analysis of variance (ANOVA) with a Dunnett's test was used to compare pEC50 values.

\section{Drugs, Chemical Reagents and Other Materials}

Serotonin hydrochloride was obtained from Toronto Research Chemicals Inc. (Toronto, Canada), methiothepin mesylate, N $\omega$-nitro-L-arginine (L-NNA), indomethacin, carbamoylcholine (carbachol), dimethyl sulfoxide (DMSO) and ketanserin (+)-tartrate salt from Sigma-Aldrich (St Louis, Missouri, USA), ondansetron hydrochloride from Selleckchem (Houston, TX, USA), GR113808, RS102221, SB699551, SB399885 and SB269970 from Tocris (Ellisville, Missouri, USA) and $\alpha$-methyl 5-HT maleate ( $\alpha$-Me-5-HT) from Abcam Inc. (Cambridge, MA, USA). Concentrations of antagonists were selected based on their relative affinities at each receptor subtype as published in the literature. A maximum concentration for a selective action was chosen that did not exert affects at the other 5-HT receptor subtypes. The concentrations of L-NNA and indomethacin were selected based on those used in the vast majority of published studies and confirmed in previous experiments in our laboratory. The concentrations of indomethacin and L-NNA were approximately 100-fold greater than their IC50 value for inhibition of COX and NOS respectively. ${ }^{18,19}$

\section{Results}

Strips of urothelium/LP developed spontaneous phasic contractions that occurred at a frequency of $3.49 \pm 0.08$ cycles $/ \mathrm{min}$ and an amplitude of $12.7 \pm 9.53 \mathrm{mN}$ per gram tissue weight $(\mathrm{n}=100)$. Cumulative additions of 5-HT induced large concentration-dependent tonic contractions of the tissue with a pEC50 of $5.36 \pm 0.16$ and maximum contractile responses of $50.43 \pm 2.78 \mathrm{mN}$ per gram tissue weight $(\mathrm{n}=100$, Figure 1). Simultaneously, 5-HT also produced small increases in the frequency and amplitude of the spontaneous contractions, the frequency increasing by $26.36 \%(\mathrm{P}<0.001)$ and the amplitude by $21.88 \%$ $(\mathrm{P}<0.001)$ during the course of a full concentration-response curve. Neither tonic contraction nor spontaneous phasic contractile activity were affected by the presence of either the nitric oxide synthesis inhibitor, L-NNA $(100 \mu \mathrm{M}, \mathrm{n}=7)$ or the cyclooxygenase inhibitor, indomethacin $(5 \mu \mathrm{M}, \mathrm{n}=7$, Figure 2$)$.

\section{Influence of selective 5-HT receptor antagonists}

Concentrations of 5-HT antagonists were chosen that would have selective actions on specific receptor subtypes and their effects on urothelium/LP responses to 5-HT investigated. Neither methiothepin (5$\left.\mathrm{HT}_{1 \& 2}, 100 \mathrm{nM}, \mathrm{n}=10\right), \mathrm{RS} 102221\left(5-\mathrm{HT}_{2 \mathrm{C}}, 30 \mathrm{nM}, \mathrm{n}=8\right)$, ondansetron $\left(5-\mathrm{HT}_{3}, 30 \mathrm{nM}, \mathrm{n}=8\right), \mathrm{GR} 113808$, $\left(5-\mathrm{HT}_{4}, 100 \mathrm{nM}, \mathrm{n}=8\right), \mathrm{SB} 699551 \quad\left(5-\mathrm{HT}_{5}, 10 \mathrm{nM}, \mathrm{n}=8\right), \mathrm{SB} 399885\left(5-\mathrm{HT}_{6}, 100 \mathrm{nM}, \mathrm{n}=11\right)$ nor $\mathrm{SB} 269970\left(5-\mathrm{HT}_{7}, 10 \mathrm{nM}, \mathrm{n}=8\right)$ had any effect on either the tonic contractions induced by 5-HT (Figure 3 ), or the maximum contractile responses (Table 1). However, the 5-HT $\mathrm{HT}_{2 \mathrm{~A}}$ receptor antagonist ketanserin caused a shift of 5-HT concentration-response curves to the right, yielding an affinity estimate of $7.9(100 \mathrm{nM}, \mathrm{n}=13)$. This shift of the concentration-response curve was greater than the shift 
observed at $30 \mathrm{nM}$ (affinity estimate also $7.9, \mathrm{n}=4)$, but increasing the concentration to $300 \mathrm{nM}(\mathrm{n}=6)$ had no additional effect (Figure 4).
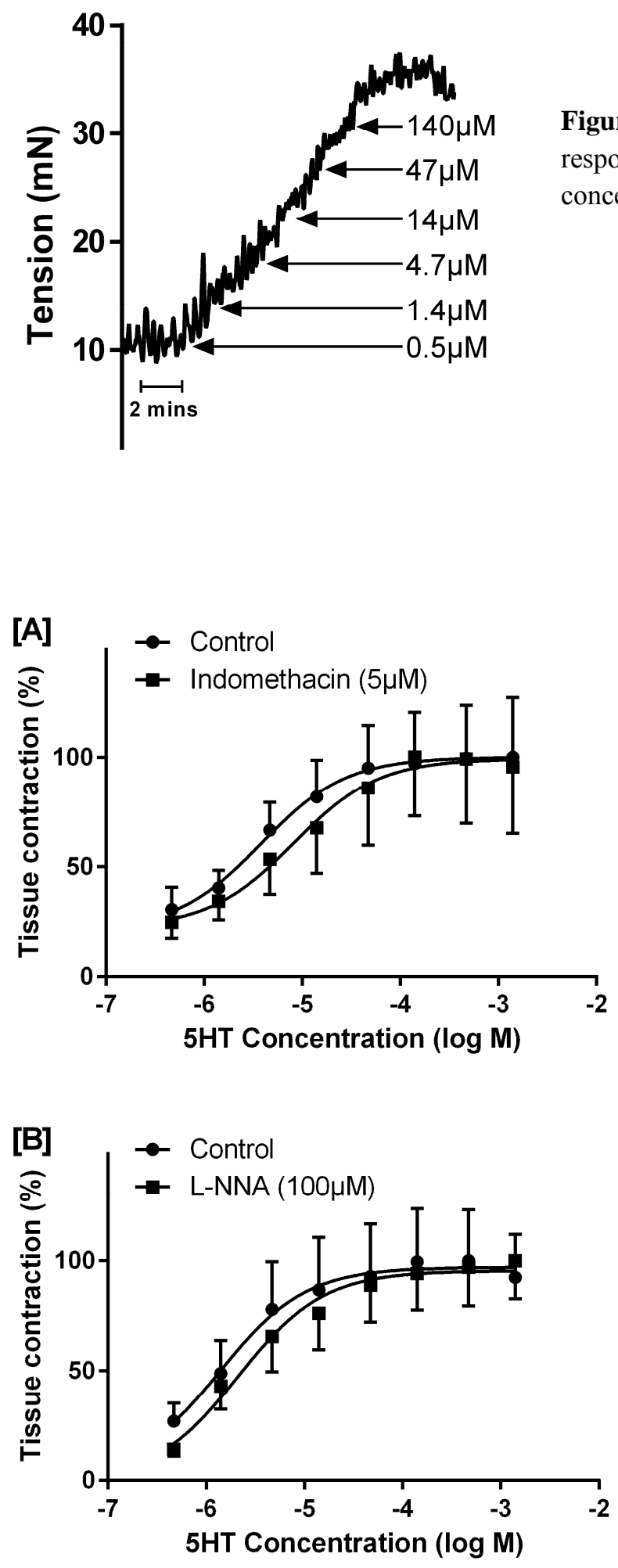

Figure 1. Experimental trace showing the responses of isolated U\&LP strips to increasing concentrations of 5 -HT.
Figure 2. Mean $( \pm$ SEM) cumulative concentration-response curves of urothelial/LP strips to 5 -HT in the absence and presence of $[\mathrm{A}]$ indomethacin $(5 \mu \mathrm{M}, \mathrm{n}=7)$ and $[\mathrm{B}] \mathrm{L}$ NNA $(100 \mu \mathrm{M}, \mathrm{n}=7)$. Responses are plotted as a percentage of the maximum contraction. 
Table 1. Calculated pEC50 and maximum contraction values to 5-HT in the presence and absence of 5-HT receptor antagonists. ${ }^{* *} \mathrm{p}<0.01$.

\begin{tabular}{lcccccc}
\hline Antagonist & nM & N & \multicolumn{2}{c}{ pEC50 } & Maximum contraction (mN/g) \\
\hline & & & Control & Antagonist & Control & Antagonist \\
\cline { 3 - 7 } Methiothepin & 100 & 10 & $5.17 \pm 0.27$ & $5.45 \pm 0.39$ & $56.38 \pm 7.54$ & $49.63 \pm 7.94$ \\
\hline Ketanserin & 100 & 13 & $5.62 \pm 0.39$ & $4.31 \pm 0.22^{* *}$ & $34.94 \pm 5.96$ & $50.03 \pm 7.15$ \\
\hline RS102221 & 30 & 8 & $5.37 \pm 0.29$ & $5.07 \pm 0.25$ & $54.00 \pm 7.94$ & $41.30 \pm 6.35$ \\
\hline Ondansetron & 30 & 8 & $5.49 \pm 0.47$ & $5.15 \pm 0.25$ & $42.49 \pm 8.34$ & $47.65 \pm 6.75$ \\
\hline GR113808 & 100 & 8 & $4.98 \pm 0.20$ & $5.29 \pm 0.26$ & $43.28 \pm 5.56$ & $43.68 \pm 5.16$ \\
\hline SB699551 & 10 & 8 & $5.44 \pm 0.47$ & $5.25 \pm 0.57$ & $32.56 \pm 7.54$ & $33.75 \pm 7.94$ \\
\hline SB399885 & 100 & 11 & $5.54 \pm 0.29$ & $5.54 \pm 0.44$ & $59.96 \pm 9.93$ & $54.41 \pm 10.32$ \\
\hline SB269970 & 10 & 8 & $5.38 \pm 0.38$ & $5.19 \pm 0.36$ & $42.88 \pm 8.34$ & $47.25 \pm 8.34$ \\
\hline
\end{tabular}



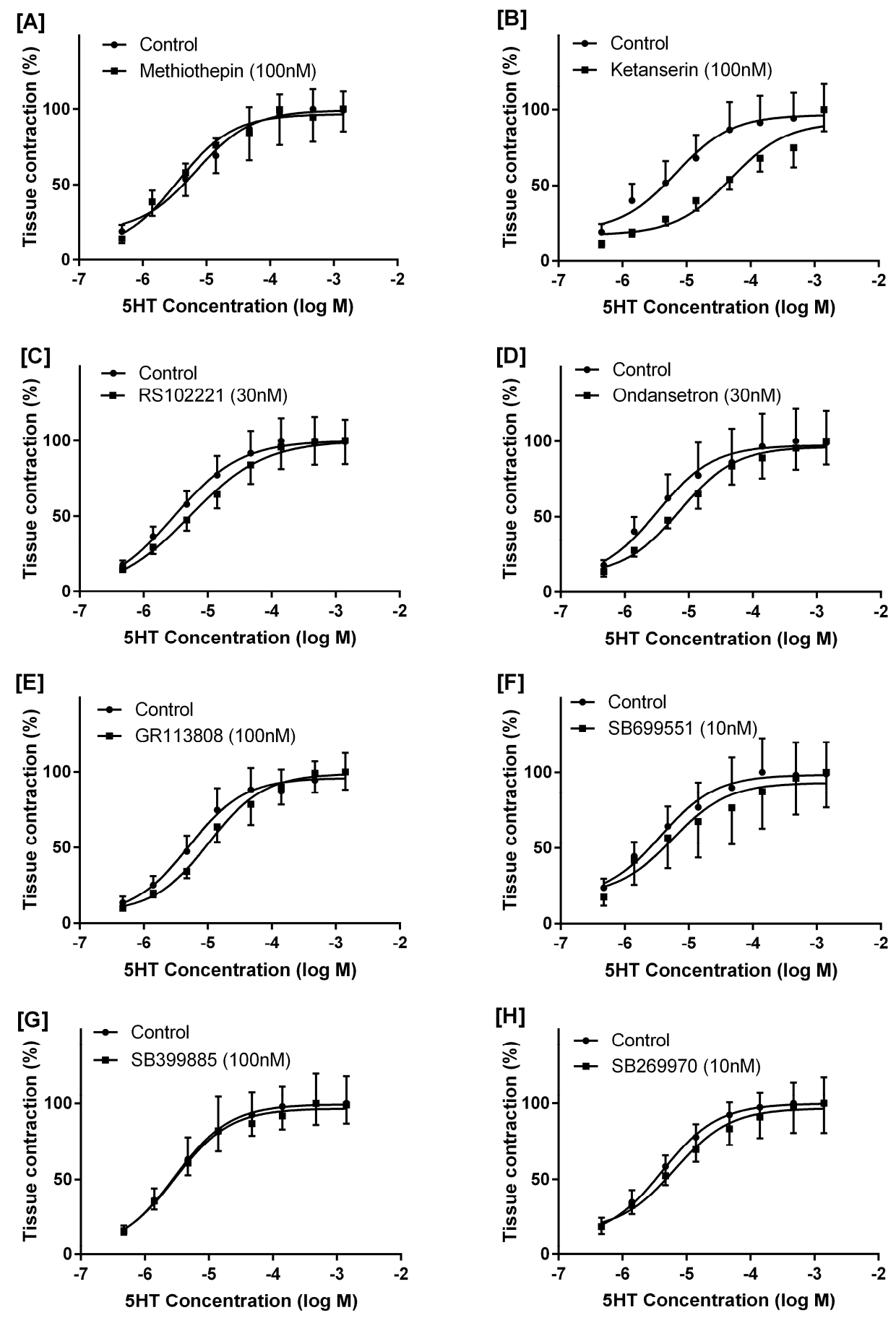

Figure 3. Mean ( \pm SEM) cumulative 5-HT concentration-response curves in the absence and presence of 5-HT antagonists $(n=>8)$. Responses are expressed as a percentage of the maximum response for each curve. 


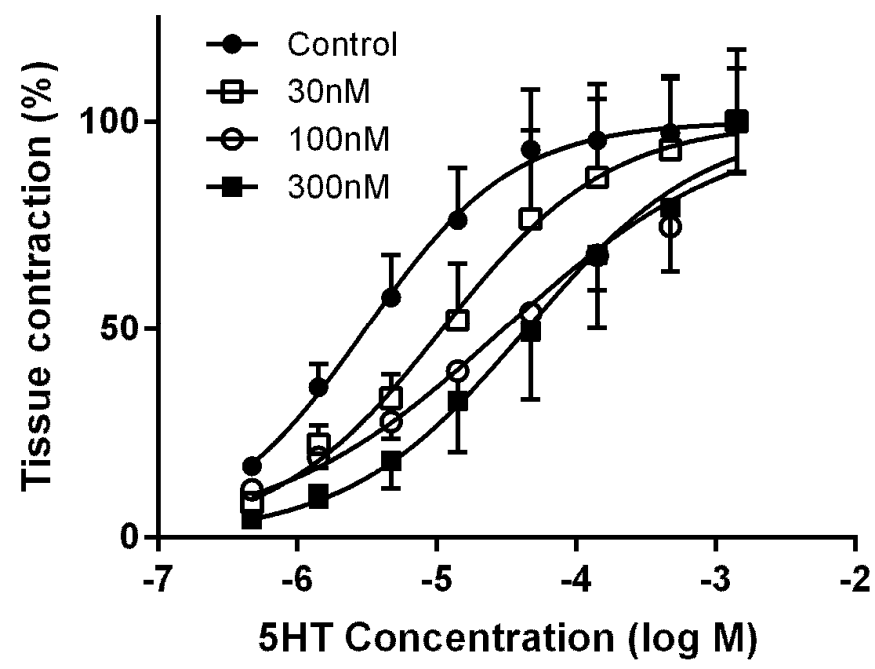

Figure 4. 5-HT concentration-response curves in the presence of $30 \mathrm{nM}(\mathrm{n}=4), 100 \mathrm{nM}(\mathrm{n}=13)$ and $300 \mathrm{nM}(\mathrm{n}=6)$ ketanserin.

Responses to $\alpha$-methyl-5-HT

Concentration-response curves were also obtained to the 5-HT2-selective agonist $\alpha$-Me-5-HT. This agonist produced concentration-dependent contractions of the isolated urothelium/LP $(n=8)$ with a mean maximum response similar to that of 5-HT (Figure 5), but had a slightly lower potency with a pEC50 of $4.94 \pm 0.09(\mathrm{P}<0.01)$. Ketanserin $(100 \mathrm{nM})$ did not significantly affect maximum responses, but produced shifts of the $\alpha$-Me-5-HT concentration-response curves similar to those observed using 5HT as the agonist, reducing the pEC50 value of $\alpha-\mathrm{Me}-5-\mathrm{HT}$ to $4.01 \pm 0.07(\mathrm{n}=4, \mathrm{P}=0.005)$. 

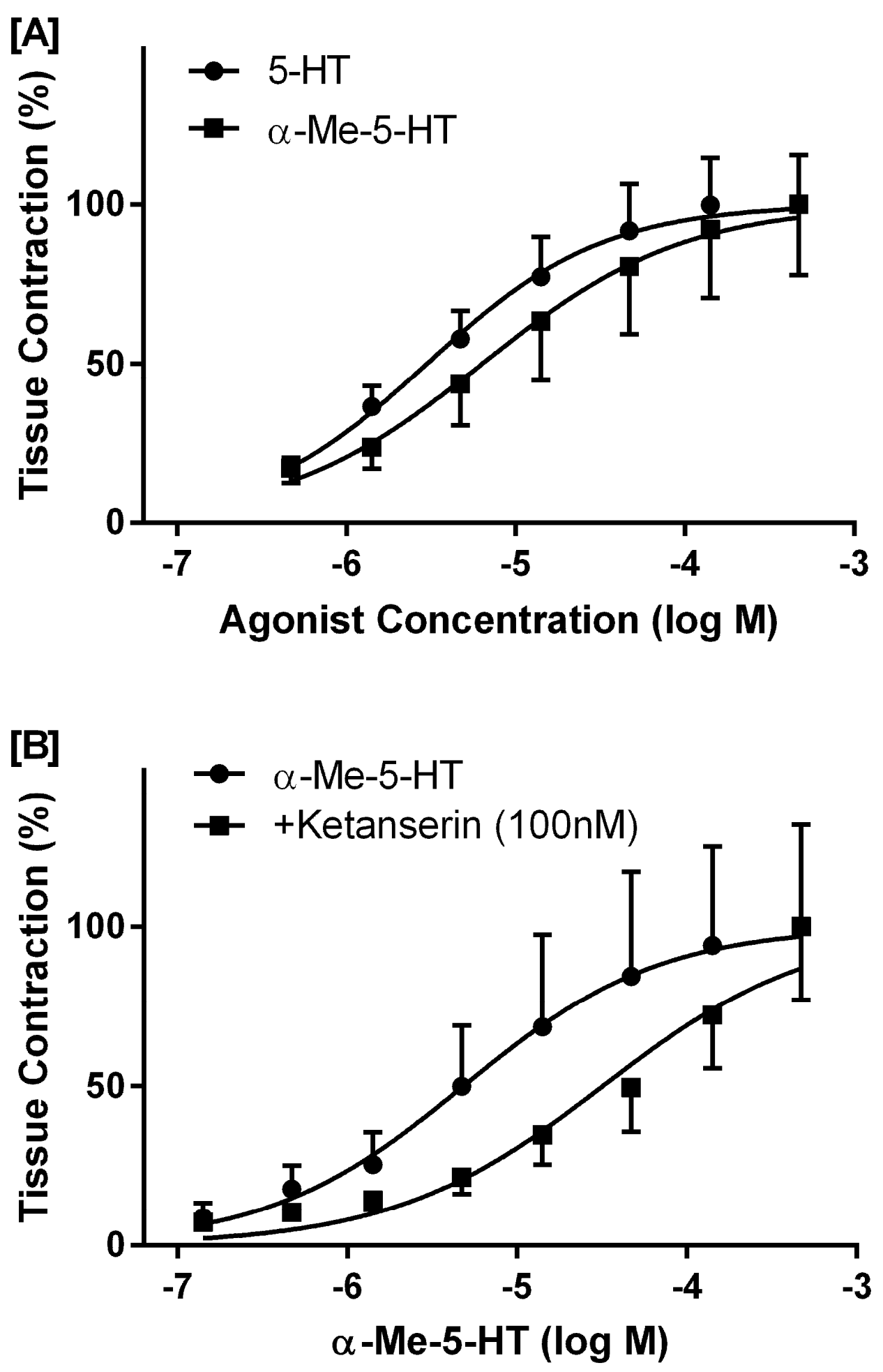

Figure 5. [A] Cumulative concentration-response curves to 5-HT and $\alpha$-methyl-5-HT in porcine urothelium/LP $(\mathrm{n}=8)$. [B] Cumulative concentration-response curves to $\alpha$-Methyl-5-HT in the absence and presence of ketanserin $(100 \mathrm{nM}, \mathrm{n}=4)$. Responses are plotted as a percentage of the maximum response. 


\section{Discussion}

The urothelium/LP was once thought to function solely as a protective barrier between urine and the detrusor smooth muscle. However, over the years it has been shown to release a number of mediators, including acetylcholine, when stretched. ${ }^{6}$ More recently, contraction of the urothelium/LP has been established in several studies, with the tissue responding to a range of stimuli including neurokinin-A, carbachol and electrical field stimulation. ${ }^{7,10}$ The tissue also possesses adrenoceptors that regulate contractile activity: alpha1-adrenoceptors enhance activity, while beta-adrenoceptors cause inhibition. ${ }^{4}$ Nitric oxide donors have also been reported to inhibit contractions of this tissue. ${ }^{8}$ The present study has investigated the influence of 5-HT on urothelial/LP contractile activity and demonstrated tonic contractile responses and increases in phasic activity.

Nitric oxide (NO) and prostaglandins are known modulators of bladder activity. NO can be released from the urothelium in some situations such as during inflammation ${ }^{20}$ and NO donors have been shown to influence the contractile activity of the urothelium and detrusor. ${ }^{8}{ }^{21}$ However, responses of the urothelium/LP were not affected by the NO synthase inhibitor L-NNA indicating a lack of involvement of NO in the 5-HT responses. Prostaglandins are also released from the urothelium/LP ${ }^{22}$ and their main role is thought to be an influence on sensory nerve activity ${ }^{23}$. A role for prostaglandins in detrusor overactivity has been suggested in the rat $^{24,25}$, where inhibition of prostaglandin synthesis can reduce bladder spontaneous activity and reduce detrusor overactivity. It is well established that prostaglandins can influence smooth muscle contraction, but they were not involved in the urothelium/LP contractile activity in the present study since indomethacin had no effect on the responses to 5-HT.

Of the 5-HT antagonists examined in this study, only ketanserin influenced responses of the urothelium/LP to 5-HT. This drug is a selective 5- $\mathrm{HT}_{2 \mathrm{~A}}$ receptor antagonist at the concentrations used. At $30 \mathrm{nM}$ and $100 \mathrm{nM}$ ketanserin produced parallel rightward shifts of the 5-HT concentration-response curve without any change in maximum responses suggesting a competitive mode of action. However, the highest concentration of ketanserin $(300 \mathrm{nM})$ failed to induce any further shift of the curve, suggesting the involvement of a second receptor at higher concentrations of 5-HT, as would be expected. Affinity values for ketanserin at $5-\mathrm{HT}_{2 \mathrm{~A}}$ receptors appearing in the literature ${ }^{26,27}$ commonly vary between $8.1-8.6$, which is consistent with the values determined in this study. A role for 5-HT2A receptors is supported by the data with $\alpha-\mathrm{Me}-5-\mathrm{HT}$, a drug that has been used widely used as a selective $5-\mathrm{HT}_{2}$ receptor agonist. ${ }^{28}$ This drug was a potent agonist producing contractions similar in magnitude to those with 5-HT and the shifts in concentration-response curves induced by ketanserin were similar for both agonists. This suggested both drugs act predominantly via the same 5- $\mathrm{HT}_{2 \mathrm{~A}}$ receptor subtype.

The results illustrate the complex nature of lower urinary tract responses to 5-HT. 5-HT4 receptors are located pre-junctionally on parasympathetic nerves in the detrusor where they regulate neurotransmitter release, $5-\mathrm{HT}_{7}$ receptors relax muscle tone in the bladder outlet region, while neurogenic contractions of the detrusor muscle appear to be via both $5-\mathrm{HT}_{7}$ and $5-\mathrm{HT}_{2} \cdot{ }^{29}$ The receptor subtype mediating muscle contraction on the porcine detrusor has yet to be established, but the present study has now identified the predominant receptor regulating urothelial/LP tone as the $5-\mathrm{HT}_{2 \mathrm{~A}}$ receptor subtype.

The physiological significance of contractile activity within the urothelium/LP is not clear. It may act to sensitize afferent nerves to maintain afferent activity that may otherwise adapt to stretch, or it may function to form folds of the urothelium when the bladder is empty. It has also been suggested that this 
contractile activity may drive detrusor contraction during bladder overactivity, ${ }^{6}$ an effect that would evolve from the increase in gap junctions identified in the overactive bladder. ${ }^{30}$ The role played by 5 HT in bladder physiology and pathology is also unknown, but the present study has identified the presence of functional 5-HT receptors in the urothelium/LP and if 5-HT is released in disease, these may represent a target for drug development to influence bladder activity.

In conclusion, this study has identified the presence of 5-HT in the bladder urothelium/LP that influence contractile activity. The predominant receptor appears to be the 5- $\mathrm{HT}_{2 \mathrm{~A}}$ receptor subtype and this receptor may represent a therapeutic target for the development of pharmacological treatments of diseases related to bladder contractile activity, such as overactive bladder.

\section{Conflicts of Interest:}

None of the contributing authors have any conflict of interest, including specific financial interests or relationships and affiliations relevant to the subject matter or materials discussed in the manuscript.

\section{References:}

1. Birder LA, Kanai AJ, Cruz F, Moore K, Fry CH. Is the urothelium intelligent? Neurourology and urodynamics. 2010; 29. 4: 598-602.

2. Wang EC, Lee JM, Ruiz WG, et al. ATP and purinergic receptor-dependent membrane traffic in bladder umbrella cells. J Clin Invest. 2005; 115. 9: 2412-22.

3. Bschleipfer T, Schukowski K, Weidner W, et al. Expression and distribution of cholinergic receptors in the human urothelium. Life sciences. 2007; 80. 24-25: 2303-7.

4. Moro C, Tajouri L, Chess-Williams R. Adrenoceptor function and expression in bladder urothelium and lamina propria. Urology. 2013; 81. 1:211 e1-7.

5. Blakeman PJ, Hilton P, Bulmer JN. Oestrogen and progesterone receptor expression in the female lower urinary tract, with reference to oestrogen status. BJU Int. 2000; 86. 1: 32-8.

6. Moro C, Uchiyama J, Chess-Williams R. Urothelial/lamina propria spontaneous activity and the role of M3 muscarinic receptors in mediating rate responses to stretch and carbachol. Urology. 2011; 78. 6: 1442 e9-15.

7. Sadananda $\mathrm{P}$, Chess-Williams R, Burcher E. Contractile properties of the pig bladder mucosa in response to neurokinin A: a role for myofibroblasts? British Journal of Pharmacology. 2008; 153. 7: $1465-73$.

8. Moro C, Leeds C, Chess-Williams R. Contractile activity of the bladder urothelium/lamina propria and its regulation by nitric oxide. European Journal of Pharmacology. 2012; 674. 2-3: 445-9. 9. Kanai A, Andersson KE. Bladder afferent signaling: recent findings. J Urol. 2010; 183. 4: 1288-95.

10. Moro C, Chess-Williams R. Non-adrenergic, non-cholinergic, non-purinergic contractions of the urothelium/lamina propria of the pig bladder. Auton Autacoid Pharmacol. 2012; 32.3 Pt 4: 53-9.

11. Berger M, Gray JA, Roth BL. The expanded biology of serotonin. Annu Rev Med. 2009; 60. $355-66$.

12. Sellers DJ, Chess-Williams R, Chapple CR. 5-Hydroxytryptamine-induced potentiation of cholinergic responses to electrical field stimulation in pig detrusor muscle. BJU international. 2000; 86. 6: 714-8.

13. Chapple CR, Radley SC, Martin SW, Sellers DJ, Chess-Williams R. Serotonin-induced potentiation of cholinergic responses to electrical field stimulation in normal and neurogenic overactive human detrusor muscle. BJU international. 2004; 93. 4: 599-604.

14. Recio P, Barahona MV, Orensanz LM, et al. 5-hydroxytryptamine induced relaxation in the pig urinary bladder neck. British Journal of Pharmacology. 2009; 157. 2: 271-80. 
15. Matsumoto-Miyai K, Yamada E, Shinzawa E, et al. Serotonergic regulation of distentioninduced ATP release from the urothelium. American journal of physiology Renal physiology. 2015: ajprenal.00024.2015.

16. Liang R, Ustinova EE, Patnam R, Fraser MO, Gutkin DW, Pezzone MA. Enhanced expression of mast cell growth factor and mast cell activation in the bladder following the resolution of trinitrobenzenesulfonic acid (TNBS) colitis in female rats. Neurourology and urodynamics. 2007; 26. 6: 887-93.

17. Imamura $\mathrm{T}$, Ishizuka $\mathrm{O}$, Ogawa $\mathrm{T}$, et al. Expression of 5-Hydroxytryptamine Receptors in Human Urinary Bladders with Benign Prostatic Hyperplasia. Advances in therapy. 2015; 32 Suppl 1. 29-37.

18. Pfeiffer S, Leopold E, Schmidt K, Brunner F, Mayer B. Inhibition of nitric oxide synthesis by NG-nitro-L-arginine methyl ester (L-NAME): requirement for bioactivation to the free acid, NGnitro-L-arginine. Br J Pharmacol. 1996; 118. 6: 1433-40.

19. Blanco FJ, Guitian R, Moreno J, de Toro FJ, Galdo F. Effect of antiinflammatory drugs on COX-1 and COX-2 activity in human articular chondrocytes. The Journal of rheumatology. 1999; 26. 6: 1366-73.

20. Andersson MC, Tobin G, Giglio D. Cholinergic nitric oxide release from the urinary bladder mucosa in cyclophosphamide-induced cystitis of the anaesthetized rat. Br J Pharmacol. 2008; 153. 7 : 1438-44.

21. Gillespie JI, Drake MJ. The actions of sodium nitroprusside and the phosphodiesterase inhibitor dipyridamole on phasic activity in the isolated guinea-pig bladder. BJU Int. 2004; 93. 6: 8518 .

22. Masunaga K, Yoshida M, Inadome A, Iwashita H, Miyamae K, Ueda S. Prostaglandin E2 release from isolated bladder strips in rats with spinal cord injury. Int J Urol. 2006; 13. 3: 271-6. 23. Rahnama'i MS, Hohnen R, van Kerrebroeck PE, van Koeveringe GA. Evidence for prostaglandin $\mathrm{E} 2$ receptor expression in the intramural ganglia of the guinea pig urinary bladder. Journal of chemical neuroanatomy. 2015; 64-65. 43-7.

24. Lecci A, Birder LA, Meini S, et al. Pharmacological evaluation of the role of cyclooxygenase isoenzymes on the micturition reflex following experimental cystitis in rats. Br J Pharmacol. 2000; 130. $2: 331-8$.

25. Rahnama'i MS, Van Koeveringe GA, Van Kerrebroeck PE. Overactive bladder syndrome and the potential role of prostaglandins and phosphodiesterases: an introduction. Nephro-urology monthly. 2013; 5. 4: 934-45.

26. Alexander SP, Mathie A, Peters JA. Guide to Receptors and Channels (GRAC), 5th edition. Br J Pharmacol. 2011; 164 Suppl 1. S1-324.

27. Sleight AJ, Stam NJ, Mutel V, Vanderheyden PM. Radiolabelling of the human 5-HT2A receptor with an agonist, a partial agonist and an antagonist: effects on apparent agonist affinities. Biochemical pharmacology. 1996; 51. 1: 71-6.

28. Baxter G, Kennett G, Blaney F, Blackburn T. 5-HT2 receptor subtypes: a family re-united? Trends Pharmacol Sci. 1995; 16. 3: 105-10.

29. Rekik M, Lluel P, Palea S. 5-Hydroxytryptamine potentiates neurogenic contractions of rat isolated urinary bladder through both 5-HT(7) and 5-HT(2C) receptors. European journal of pharmacology. 2011; 650. 1: 403-10.

30. Ikeda Y, Fry C, Hayashi F, Stolz D, Griffiths D, Kanai A. Role of gap junctions in spontaneous activity of the rat bladder. American journal of physiology Renal physiology. 2007; 293. 4: F1018-25. 